\title{
From Zheng He to Koxinga \\ -The Development of the Armed Sea-merchant Group of Late Ming Dynasty and Their Effort to Defend the Sea-power
}

\author{
Zilai Zeng ${ }^{1}$ \\ ${ }^{1}$ Chengdu University of Technology, China \\ Correspondence: Zilai Zeng, Chengdu University of Technology, China. E-mail: zz194417@163.com
}

Received: December 18, 2014 Accepted: December 28, 2014 Online Published: January 12, 2015

doi:10.5539/ach.v7n2p1 URL: http://dx.doi.org/10.5539/ach.v7n2p1

\begin{abstract}
This article aimed at the efforts that the armed sea-merchant groups made to defend the sea-power of China and their development in the late Ming dynasty. The basis of the study rely on the historical records at home and abroad.The study of this topic shows that early in the $17^{\text {th }}$ century, Chinese sea-merchants had become a strong competitor in the struggle of sea-trade and sea-power in the eastern and southeastern Asia.Furthermore, the study shows that the sea-merchant groups of China already had a clear understanding of the importance to defend the sea-power, and they were familiar with using the economical and military ways to deal with the western competitors. Furthermore, their relationship with the government gradually changed to cooperation over time. The article finally contributes towards an improve understanding of the glorious deeds of ancient Chinese sea pioneers and provides new ideas of the modern sea-power strategies.
\end{abstract}

Keywords: sea-power, Koxinga, armed sea-merchant group, Late Ming Dynasty, Zheng Zhilong

\section{Preface}

The topic about Koxinga and the armed sea-merchant groups of the Ming Dynasty has already been widely discussed by the Chinese and international academic circles, but the focus and range of the former researches are on the character, military force, trade volume and their management on Taiwan.Of course, recent years more and more scholars noticed the particularity and importance of Zheng family group, for example, "The fall of Zheng family group caused that Chinese culture lost a great chance to get herself renewal" (Wang, 2005). At the same time, some historians also noticed the inspirations that the Zheng group's efforts to protect the sea-power could bring to us, for example, "The efforts to defend the sea-power by the maritime merchant-military power which was represented by Zheng family group could give modern China which is in transition some really important inspiration" $(\mathrm{Ni}, 2012)$. My research has benefited from the research achievements of the predecessors a lot.

However, most researches on the sea-merchants groups of Ming dynasty only focus on Koxinga and his father Zheng Zhilong, and lack a general view on the whole developing process of the sea-merchant groups. For example, historians like Wang (2005), Ni (1997), and Tan (2010)'s thesises all focus on Zheng family group only, and didn't regard it as a part of the whole developing process of sea-merchant groups of Ming dynasty. Besides that although there has already been some discussions on the inspirations that Zheng family group could bring to us, but the discussions are far from comprehensive, and the studies on the strategies that Zheng family took to defend the sea-power are also far from enough. For example, in Ni Lexiong's thesis, he only focus on the general inspirations that Zheng family could bring to modern China, for example, the importance for a modern commercial state to have a strong navy, but the analysis and conclusion of him are far from comprehensive (Ni, 2012). And I think we should revalue the true historical significance of Zheng family group on the basis of previous studies. And as for today's China, to defend the sea power is the theme of the era. So, it's really necessary to strengthen the research in this area.

\section{Chinese Maritime History Before the Late Ming Dynasty}

China has long and tortuous coastline, and since ancient times, China always played really important role in the International maritime trade.After some hundreds of years' development, at the beginning of Ming dynasty, the Emperor decided to sent Zheng He to conduct a great navigation. 
At the same era of Zheng He, whatever the extent of fleet or the size of ships, the Zheng He fleet must be the only super power in the sea in his times. But because of the lack of enough Economic drivers, and facing more and more great stresses especially from the literati class, finally, the great navigation led by Zheng He ended really hastily. What made the situation more regretful is that the historical data of Zheng He and his fleet was destructed by people intensively.

After the death of Zheng He, the navy even the coast defence of the Ming Dynasty were completely abandoned, which soon gave the Japanese pirates and the later armed Maritime Group a God-given chance to rise up sharply.And the development of Japanese pirates and the armed sea-merchants groups was intensified by the continuous strict sea-trade forbidden acts of Ming government.

To make things more complicated, after the Great geographical discovery, the western powers poured into the Southeastern and Eastern Asian sea area. They united with the local sea-merchants groups and confronted with the Ming government together. And the most representative leader of sea-merchants groups this time was the famous "the owner of Wu feng ship" - Wang Zhi.

Wang Zhi once rely on the steady union with the Japanese warlords and the westerners, established a great sea Empire in his own power, but, finally he was cheated by the officer of Ming government Hu Zhongxian, and came back to the mainland, then was beheaded there.

From the start of $16^{\text {th }}$ century to the time that Wang Zhi was beheaded, that half century time was the time that the sea powers of old-east and rising-west first met and integrated. According to my research, I think that there are not enough attentions that have been paid to this time's China and western relationship and the historical significance of Wang Zhi. At this time, Ming government still had really strong ability to control, and carried out some really strict sea policies. As a result, the nongovernmental sea power groups prefer to cooperate with the westerners to balance the strong Ming government. By the way, the western countries also lacked enough power to fight against Ming empire alone at that time. As a result, the struggle for sea power at that time was mainly concentrated on the contradiction between the sea-merchants group and the central government. In general, it's a time that the eastern and western sea-powers cooperated most of the time, and fought together against the strong centralization of Ming Empire.

\section{From The Opening-Up Policy of Longqing Emperor to the Sea Empire of Zheng Zhilong}

\subsection{The Opening-Up Policy of Longqing Emperor}

After years of so-called anti-Japanese pirates wars, the Ming government finally realized the seriousness of the sea-trade forbidden Acts. Especially after the rising and falling of Wang Zhi group, most of the reasonably informed officers of Ming empire started to realize that the sea-trade forbidden Acts had already become the important reason of the crisis and invasions of the sea.

In the year 1567, the governor of Fujian Tu Zheming submit a memorial to the emperor that "Please cancel the sea-trade forbidden Acts and permit the merchants to trade around the western and eastern oceans" (Zhang, 1985). His requests were quickly approved by Emperor Muzhong, although the government only opened Fujian province Zhangzhou's Yue port as the only open port, but it's still a great progress at that time. After that, as the authoritativeness of Ming government had gradually fallen down, the sea-trade forbidden Acts which lasted for more than 200 years had actually been abolished, and the gate of China which had been closed by Ming government for a long period finally opened slightly again.

The influence of The Opening-up policy of Longqing emperor was very profound and lasting. Even the historians like Li Guoqiang, Liu Junke who preferred to agree with the view that the general trend of Ming dynasty's marine policy is inward oriented agreed with the opinion that the Opening-up policy of Longqing promoted the development of the trade of coastal area (Li \& Liu, 2014). As far as I am concerned, at first, after The Opening-up, there was quickly a great wave of silvers that inflow into China, which led to a period of time's great economic prosperity of Ming dynasty, but the extreme inflation it brought had also buried the foreshadowing of the end of Ming Dynasty. Secondly, because the maritime embargo policy became much easier than before, the nongovernmental sea-merchant groups recovered and kept sustaining development, and began to expand the trading limit and power to the southeastern Asia again. At the same time, the biggest enemy and competitor gradually changed from the Ming government to the western Colonial Empires, and the contradiction between both sides escalated, finally changing into a relationship of competing and fighting with each other.

These all above were the main eastern background of the next 100 years' sea-power struggle.

\subsection{The Growth and Decline of the Eastern and Western Powers}

Just at the same time of China's opening policy, the western powers in the southeastern Asia soundlessly changed a lot. 
The first point, was the gradual falling down of Portuguese and the rising of Hispanic powers in the eastern Asia. As the silver mines of Hispanic America had been found and mined, and the national power of the Habsburg Spain was just like the sun in broad daylight. Besides, in 1580, king Felipe II of Spain conquered Purtuguesa, and became the king of her. As a result, Spain became the most important western country that traded with the Asian countries and established colonies there, too.

Second reason is the risen of Netherlands. After the religious reform, the commonwealths of Netherlands which had belonged to Spain before became independent. Because they had advanced political and economic systems, the Netherlands quickly rose in the sea, and entered Africa, southern Asia and the Eastern Asia, got the name of Sea coachman, and became a powerful competitor of Spain.

But, when the self-satisfied western colonists entered the southeastern Asia sea-area, they will find that they had to face the unprecedented great challenge.

There were many excellent sea heroes of Asia existing this time, and the most famous two of them were Lin Daoqian ${ }^{(C a i, 1967)}$ and Lin Feng. They were all the leaders of Chinese sea-merchant groups who fought against the western colonists in the southeastern Asia. It is worth mentioning that Lin Feng had a plan to capture Manila from the Spanish, although they were all failed at the end.

The common tragedy of Lin feng and Lin daoqian is that they were both between two fires. They were both the thorn in the Western colonists and Ming government's flesh. This also shows their transitivity, they had both the past pirate's character to fight with the Ming government, and the new great ambition to compete with the westerner about the sea hegemony, and this was the deep reason of their tragedy. But, their blood did not waste in vain, just after a while, the synthesizer and the leader of a new time appeared, he was Zheng Zhilong, and he drew lessons from them, and established a sea Empire of the new time.

\subsection{The Accumulation of Strength and Gradual Rising Up of Zheng Zhilong at Early Age}

Zheng Zhilong, the pet name of him was Iquan, had a Catholic Christian name called Nicholas. He was born in the Nanan county of Fujian province in 1604. And his early experience and rising process can't be divided from several famous sea heroes in his age.

Just like many merchants of Fujian, he had traveled around many ports of southern ocean countries, he had ever came to Macaw and Manila, and had been baptized in a catholic church. Later, he came to the important port Hirado of Japan, and became the follower of a famous leader of overseas Chinese, Lidan. In 1624, he was sent to Penghu, and acted as a translator between Ming government and the Netherlands, which was a starting point of his whole career.

At that time, Li Dan had a really strong sea power. He originally came from Quanzhou port, and in his early age, he stayed in Manila to develop his own strength. But because the Spanish feared the strength of Chinese grew too fast, and conducted the first anti-Chinese movement in the history, and Li Dan lost all the wealth he had in the Luzon islands for many years, and had no choice but to come into Japan which was in the control of Tokugawa Shogunate then. And later he became the owner of red seal ships, and established strong power in the area north to Japan and south to the Manila and Sumatra. The famous Chinese leader of the same time Yan Shiqi may be his assistant or confederate, the sea group which was established by the two people became the basics of Zheng Zhilong's sea Empire.

Around 1625, Li Dan died in the way between Japan and Taiwan, at the same year, another famous Chinese merchant leader Yan Shiqi passed away, too. The division of powers among the Eastern Asia seas faced a completely new recombination. After three years' civil war, Zheng Zhilong officially succeed the career of Li Dan, and became the leading power of Chinese sea-merchants groups.

\subsection{A Soaring Dragon - The Golden Age of Zheng Zhilong}

The quick rising up of Zheng Zhilong made the Netherlands very worried, the Dutch governor of Formosa said in his report to the headquarters of the Dutch East India Company that: "The Chinese pirates developed really soon, and they nearly took control of the whole China sea. ... and the leader of them was called Iquan (Zheng Zhilong)" (Xue, 2011). So, the former union relationship between Netherlands and Zheng Zhilong in the early age gradually came into an edge of collapse.

To avoid fighting on both sides, and get enough immigrants to develop Taiwan from the mainland, Zheng Zhilong found the common interests with the struggling to cope with the serious sea condition's Ming government, and Zheng Zhilong received the amnesty from Ming dynasty, and his sea group suddenly changed into the official army, and in a legal identity to continue his great blueprint of sea power. 
Firstly, Zheng Zhilong organized for the first time in history to immigrated in a large scale to Taiwan. As Zheng Zhilong inherited the foundation of Yan shiqi's development in Taiwan, and used Liang port as the base. To increase the numbers of population in Taiwan, and strengthen the economical power, Zheng Zhilong advised the Ming government to take the measure of " 3 gold and 1 bullock" (To give one people three Liang of silver and give each 3 people a farm bullock) to encourage the immigration to Taiwan, and successfully made ten thousands of hungry people immigrate to Taiwan island, and accelerated the development of Taiwan island.

Secondly, Zheng Zhilong built up a really comprehensive business system called "The five Merchants", and it could be divided into the "The mountainous five Merchants" and "The five Merchants of sea" two parts. "The mountainous five Merchants" was set in Hangzhou and the nearby areas, and there were five branches which were named by the old Chinese five elements: metal, wood, water, fire and earth. Their missions were to purchase silk, china and the antiques to Xiamen, and in Xiamen, "The five Merchants of sea" were responsible to sell these goods through great merchant fleet to the far places like Northeastern Asia and Southeastern Asia. Such size of organization and maturity degree never appeared in the Chinese business groups before.

At the same time, Zheng Zhilong combined the red seal system of Japan and the similar systems of Western countries to create the "Lin qi" system, insuring the safety for the ships that sailed in the sea. If the owners of ships gave enough protection fees to the Zheng family, they can hang up the flag made by Zheng family, and be protected by the sea power of Zheng group. That's really a big step to enlarge the influence of power and comprehensive strength of the group of Zheng family.

Furthermore, Zheng Zhilong also had a really open international sight and a modern mode of thinking.

The Dutch worried a lot about Zheng Zhilong, the rising competitor of sea, which could be reflected from the first two Trade agreements that The Dutch signed with Zheng family. In 1628, when Zheng Zhilong signed the first trade Agreement with the Dutch, at that time, the strength of Zheng family was far less than the Dutch East India Company, so in the agreement, the main content was about the duties that Zheng Zhilong should undertake but only a few clauses about what The Dutch should assume. But in the only two years later's second Agreement, it's apparent that the Dutch relied on Zheng Zhilong much more, and the Dutch needed the help of Zheng Zhilong to break through the key links of Ming government to strengthen their trade with China, and Zheng Zhilong hoped that The Dutch could helped him to destroy other sea merchants groups.

But, such kind of cooperation didn't last very long. The Netherlands was the super power of sea this time, they weren't satisfied with the limited open policy that Ming government offered, and they were even more angry with the monopoly of the trade between Fujian and Taiwan of Zheng Zhilong. They decided to take threatening measures like the later Opium War to destroy the Zheng family group and forced the Ming government to open for trade completely. In their own words, they will "plunder the Chinese Fujian coastal areas to force the Chinese government to receive the trade demand of us" (Xue, 2011)

In July, 1633, the fleet of Netherlands suddenly attacked the Xiamen port, and Zheng Zhilong was caught off guard, and was beaten heavily. Zheng Zhilong hadn't decided to make a final bid for victory with the strong Netherlands, sent messengers to ask for peace several times, but the Dutch didn't receive it, and put forward many harsh requirements to Zheng Zhilong and the Ming government, which made Zheng Zhilong had no choice but to make a final bid for victory with the Dutch. The Dutch cooperated with another pirates group led by Liu Xiang, and had a greatest sea warfare between Eastern and Western world in the history until this time. Finally, the overbearing Dutch navy was beaten heavily, and escaped from the battlefield in a tight corner. According to the Chinese official history books: "In the era of Chongzhen, The Dutch was beaten by Zheng Zhilong, and was afraid to plunder the mainland for years" (Zhang, 1974). The victory led by Zheng Zhilong prevented Ming government from falling into a destiny like Qing government suffered after the Opium War, and kept the completeness of China's sovereignty and sea power. And the prestige of Zheng Zhilong reached the highest places, just like the sun in broad daylight. And he was honored by the Ming government to be "The Greatwall of the sea", it's the first time in history that the Ming government had cooperated perfectly with the pirates.

After the crushing defeat, the Dutch drew a conclusion that "The free and limitless Chinese trade can't be gotten by the way of force and violence" (Chen, 2000), and they decided to make peace with Zheng Zhilong. Through such peace treaty, Zheng Zhilong restart the channel to the far Southeastern Asia, and destroyed the final competitor in the coastal area - the Liuxiang group, and established an unprecedented sea Empire. At that time, "There are really silent around the sea (There were no more battles and conflicts around the sea), and the ships that sailed around oceans and the merchants from both China and foreign countries, all used the flag of Zheng family, and then they will meet no troubles in the sea, and the benefits the merchants got were 20 times bigger than ever before", "The trade ships without the flag of Zheng family can't sail to other places freely" (Ji, 1984), "Many countries all used 
the flag of Feihuang (Zheng family), and to sail in the far oceans and seas just like to travel in the mainlands of China". In the rough Western Pacific ocean, it's the first time to appear the peace under the rule of Zheng Zhilong.

At that time, the army under the command of Zheng Zhilong was more than 200000 people, and the nationalities of them divided from China, Japan, Korea, Western countries to even African blacks, the number of ships in his fleet was more than 3000, and the Taiwan Strait completely became the inland sea of Zheng family, the Zheng Zhilong group rose to be the strongest sea group of the Western Pacific ocean. That's the most glory time of the whole life of Zheng Zhilong, too.

\subsection{Brief Summary}

From the time when Wang Zhi was beheaded to the Golden era of Zheng Zhilong, was about a century, and this was a really fast developing century.

Although there has already been some researches mainly aimed at Zheng Zhilong and his sea-empire before, but, the theses focus on the relationships between Zheng family group, Ming government and the Dutch are very rare, and even some theses, for example, Xia Beibei's thesis noticed that "The relationship between Zheng Zhilong and the Dutch is occupied by competition and distrust for the most of time" (Xia, 2002), they didn't take the relationship between Dutch, Zheng Zhilong and the Ming government as a organic whole, any changes in among the three sides will influence the relationship among them. That's the point I think we could strengthen the study on Zheng Zhilong and his group.

First of all, in terms of the relationship between the nongovernmental sea merchant group and the central government of Ming, they were gradually came from struggle to cooperation. At first from the death of Wang Zhi, the nongovernmental power felt distrust on the government and the government cooperated with the western power to destroy the sea merchants groups. Then the relationship got closer because of the rising of western power, then the two sides completely flowed together. In that nearly a century's time, the relationship between official and sea-merchants went through a long process.

Secondly, in terms of the relationship between the civil power and the western countries, it came from cooperation to struggle. With the significant strengthening of western powers in the west pacific ocean, the western powers gradually became a great competitor and enemy for the Eastern Asian sea-merchant groups. But the Asian sea-merchant groups quickly found the ways to cope with the westerners, and finally they gained the upper hand over the western power.

Finally, in the strategy of sea power, this stage's sea-merchants groups had already had a strong concept of the sea power. For Lin Feng and Lin Daoqian, or the later Zheng Zhilong, they all struggled with the westerners for the sea power of Chinese in the Eastern Asia and the southeastern Asia. Especially the brighter younger generation Zheng Zhilong, he organized his sea group, and established a lot of systems to manage the sea affairs. By the way, he took the modern ways of diplomacy to negotiate with the western countries about the politics and the economic affairs, and signed a lot of agreements and treaties which were basically equal and slightly benefited the Asian. At the same time, he learned from the advanced western science and technology, improved the equipment level of fleet, established a modern navy which never appeared before in Asian history, and beaten the Dutch fleet in a key battle, protected the integrity of Chinese territory and sea power, and he also successfully protected and enlarged the Chinese power's rights and interests and international impact in the East and south Asian sea-areas, which contributed a lot to the whole Chinese nation and Asian people.

\section{The Mainstay - Zheng Chenggong, the Hero Who Sustained the Whole Risks}

\subsection{A Sudden Change in the Situation - The Fall of Ming Empire and the Entry of Manchurian}

Just at the same time when Zheng Zhilong was enormously proud of his success and tried hard to make the strong sea Empire that he built by himself better, his motherland, Ming Empire's condition was getting much worse.

In 1644, Li Zhicheng, the leader of the insurrectionary Army, finally captured the 300 years capital of Great Ming Empire - Beijing, Emperor Chongzhen hanged himself in Meishan, and the whole China fell into great chaos.

What made it much more dramatic was that only after nearly a month's time, the overbearing Li Zhicheng was beaten heavily by the cavalry of Manchurian, and the Manchurian who was as fierce as tigers and wolves conquered the mainland from that time.

\subsection{Samson at Gaza - The Miscalculation of Zhengzhilong to Surrender to the Manchurian}

When the Manchurian conquered Nanjing, Zheng Zhilong asked his brother Zheng Hongkui to protect the Tang king to Fuzhou, and Zheng Zhilong crowned him to be the Emperor, and established the Longwu government. And Zheng Zhilong was awarded the title of Marquis, and became the actual ruler of government. And his eldest son 
Zhengsen presented himself before the Emperor, and was loved by the emperor. He was then been given the same family name as the royal family, and changed his name to Zhu Chenggong. This is the reason why people called Zheng Chenggong as Koxinga.

Although the emperor himself was crowned by the Zheng famliy, he tried everything to constrain the power of Zheng Zhilong, and Zheng Zhilong was really angry about it. Moreover, the pressure of the Manchurian armies became greater, and gradually the idea of surrendering to the Manchurian came into Zheng Zhilong's mind.

The decision that Zheng Zhilong made to surrender to the Manchurian was objected by his eldest son and his brother, his eldest son Zheng Chenggong even knelt down and persuaded that: "Just like that the tigers couldn't leave the mountains, and the fish can't leave the lakes. If a tiger leaves the mountain, he will lose the prestige he had before, and the same as the fish who leaves the lake. We just make the same thing like they did. Please think about it more and change the decision!" (Jiang, 1960). But Zheng Zhilong stuck to his idea, and believed that after surrendering to the Manchurian he can still keep his sea Empire, and even get more benefits, so he was determined to surrender to Manchurian.

Zheng Chenggong had no choice but to flee. He led 20s of people to the Confucian Temple and prayed that: "Before today, I'm only a young boy. After today, I will be the only loyal courtier of Ming Empire. To give up or to hold it on, that will be decided by our own will. We will take off the clothes of scholars, and hope your soul will understand us in the heaven" (Huang \& Wu, 1996), then he flee to Jinmen. And Zheng Zhilong came to negotiate with the commander of the Manchurian, but the commander Boluo broke his promise, and put Zheng Zhilong to house arrest, then taking him and his sons back to the north. No man is wise at all times, the same as Zheng Zhilong, he finally was blinded by lust for benefits, and the sea Empire that he fought for his half life time was nearly in the edge of collapse.

\subsection{The Mainstay - Zheng Chenggong, Who Supported the Crisis Along}

Fortunately, as ambitious as Zheng Zhilong, he had such a dashing and spirited son like Zheng Chenggong.

Zheng Chenggong, formerly known as Zheng Sen, whose pet name was Fusong, is the eldest son of Zheng Zhilong and his Japanese wife. "He had the boldness and resolute which was inherited from his mother, and the Machiavellian methods and resourcefulness which were derived from his father" (Zhang, 2009). Zheng Chenggong who had both the blood from Chinese and Japanese had the greatest qualities of the two nations, and he received the education of Bushido in Japan when he was very young. He returned to China when he was 7 years old, and was influenced by the patriotic idea and loyal to the throne of the ancient Chinese. Then he took great scholar Qian Qianyi as his teacher, and was deeply influenced by the Confucianism.

After his father didn't listen to advice and surrendered to the Manchurian, Zheng Chenggong flee to Jinmen to avoid for a moment. Then the Manchurian army acted perfidiously to invade Nan'an, which is the hometown of Zheng family. Zheng Chenggong's mother who returned from Japan just before that was caught by the Manchurian army, and she didn't fear the overbearing soldiers, finally "used the sword and Seppuku to commit suicide resolutely" (Jiang, 1960). Zheng Chenggong cried hysterically after hearing the grievous news, and buried his mother in the Japanese way, then swearing not to exist together under the same heaven with the Manchurian. In January, 1647, Zheng Chenggong swear to fight against the Manchurian government in the name of the loyal courtier of Ming dynasty (Jiang, 1960).

But, because of the surrender of Zheng Zhilong, Zheng family group, which once united like a sheet iron, split greatly, and the power of Zheng Chenggong was not enough. He even only had thousands of soldiers at the beginning, and was unable to contend with the Manchurian army. Besides Zheng Chenggong lacked a consolidated base. In 1649, Zheng Chenggong admitted Emperor Yongli's government to be the legitimate successor of Ming dynasty, and was awarded the title Yanping king by the Emperor. He also got a new flag to fight against Qing government, which made his momentum recover for a while, but his group still lacked the potential and developing space in the long term.

To get a more consolidated base, Zheng Chenggong received the advice from Shi Lang, sudden striking Xiamen port which was controlled by his two uncles. Then he got a more consolidated base. But later when he led his army to protect the Yongli emperor from danger in Guangzhou, the Xiamen port was weak of guard, so the Qing army took the chance and robbed everything there, "The things that Zheng Zhilong accumulated for his whole life, the achievements that Zheng Chenggong got for these years, were all lost in that disaster" (Xue, 2011). The power of Zheng Chenggong was beaten heavily. One disaster after another is that the important general Shi Lang of Zheng family flee to Qing government this year because of infighting, and Zheng Chenggong killed all his family members because of rage, and they became deadly enemies from then on. 
Although Zheng Chenggong failed many times in his fighting against Qing government, however, he was a successful heir for the great sea Empire his father created. He continued to use the rules and organizations that created by his father, and the Navigation scope of his group was far in the whole southeastern Asia, and he owned "Thousands of great ships, hundreds of generals, and more than 200000 soldiers" (Jiang, 1960). His group was still the greatest competitor of The Dutch East India Company. And the flags of Zheng family and the name Koxinga were still the safest passport of the Chinese ships who sailed in the Southern ocean, and the oversea Chinese people were protected by the Zheng group in many ways.

But, because Zheng Chenggong always lacked a consolidated base which could provide enough provisions and funds for troops in the mainland, the great army's provisions and funds had to be gained from the oversea trades, which made the Dutch could use the way of pirate's actions like plunder to balance and attack the power of Zheng family. To maintain the navigation safety in the China-seas and the Southern oceans, Zheng Chenggong warned the Dutch many times, and sent his fleet to attack the Dutch sea power. A classic example was in 1655, to combat the arrogance of the Spanish government of Manila who conducted the anti-Chinese action for many times, Koxinga ordered all the ships under his power to lay an embargo on Manila, and notified the Dutch government of Formosa to take common measures. But the Dutch turned a deaf ear to the requirement, and continued to trade with Manila. This really made Zheng Chenggong very angry, and he asked all the ships and sphere of influence that under the power of Zheng family, laid a total embargo on the Netherlands Taiwan. Only after a year, The Dutch couldn't hold on any longer, asked for peace on their own, and finally reach an accommodation in the condition of paying tribute annually to Zheng family, allowing Zheng group to levy taxes on the Chinese who lived in the Taiwan island.

According to this example, Zheng Chenggong knew and could take some extremely flexible ways to protect his own group's sea-benefit. Furthermore, the measures he took were mainly the economical measures, and the force threats were the supplements. This is a really farsighted thought to protect the sea power. Even in today, it is really an instructive thinking mode.

In 1655, because of the far distance between the Yongli government and Zheng Chenggong, the Emperor permitted specially Zheng Chenggong to set six departments and appointed officials. From then on, the independent government of Zheng family, took on the early embryo. And Koxinga ordered to change the name Xiamen to Siming, to show his respect to the royal family. In 1659, Koxinga launched the biggest northern expedition in his life, and his army marched smoothly at the beginning. The advance of Zheng army shocked the whole big area to south of Changjiang, and the people there took off the Manchurian clothes and cut down the pigtail one after another, and they cried to each other that: "We have not seen the dress and clothes of Great Ming for such a long time!" (Koxinga, 2014). Unfortunately, Koxinga was cheated by a delaying tactic, and finally was beaten heavily under the walls of Nanjing city, and had no choice but to withdraw. This is not only the top of Zheng Chenggong's career to fight against the Manchurian, but also the turning point of his whole life.

After that crushing defeat, Zheng Chenggong recalled the past pain, and started to consider the question how to get a consolidated base to fight against the Qing government.

\subsection{The Fighting Dragon - Zheng Chenggong's Recovery of Taiwan}

Taiwan, had some related records in the early books like The Records of Three Kingdoms and Book of Sui. And in the time of Ming dynasty, it was always the important base and supply place of the sea-merchant groups like Wangzhi and Zhengzhilong. In 1624, the Dutch East India company which failed to occupy the Penghu islands had to turn into Taiwan, and established the Zeelandia city, and started the Netherlands Taiwan's time. Not after long, the Spanish occupied the northern Taiwan from Manila, competed with the Dutch power for a long time, until they were driven away by the Dutch in 1642. At the same time, Yan Shiqi and Zheng Zhilong's groups still had some influence power in the Taiwan island, too.

So, when Zheng Chenggong started to plan to conquer Taiwan, he used the name to recover the lands that his father had: "Taiwan, was the land that our family had before, I will recover it to settle down the refugees" (Xue, 2011). At the same time, a man from Quanzhou worked as a translator in Netherlands Taiwan for many years. From long ago he transmitted the messages of the Dutch side to Zheng family, and worked as a spy in fact. When he flee back to Xiamen in the spring of 1660 , he persuaded Koxinga to strike Taiwan: "Taiwan has thousands of square kilometers' abundant land, was indeed the place a conqueror lived in. If we got that land, our power could be much stronger, and we can let the people cultivate here and make the supply of our army become adequate. Through that, we can make our country rich and make our army strong, and we will be flexible to choose to attack or defend, which will be surely enough to fight against the Qing government which controlled the mainland" (Jiang, 1960). He also dedicated the map of Taiwan which he prepared for a long time, which made Koxinga very interested this 
time and prepared to send troops. But because of his new failure in Nanjing, and the steady push forward of Qing army, he had no spare power to attack Taiwan at that time, so he laid the plan aside for a while.

Then next year (1661), Zheng Chenggong beat Qing army, and successfully held the Xiamen port. He did his utmost to hold his own opinion against that of the majority, deciding to attack Taiwan. When he reached Penghu islands, although there were all against the wind in the roads ahead, Zheng Chenggong was determined to captured Taiwan, and he made the decision to sail against the wind, when his ships reached the Luermen, spring tides suddenly came, and his army landed successfully, and won the first battle of war, then surrounded the city of Provintia. At this time, there were only 140 soldiers and forage for 5-6 days in the city, after being surrounded for several days, the Provintia city gave up, and surrendered to the Zheng army.

At this time, the Taiwan aborigines and the Han people who had been suffered from the government of the Dutch mostly rose up in arms, and helped the Zheng army to fight against the Dutch tyranny. And according to a Dutch missionary called Stewen Jansz's records, "All the residents were surrendered to the Zheng army, and they had no respect to the Dutch anymore". The govern of Netherlands had already become swaying in the midst of a raging storm.

At the same time, Koxinga led his army surround the Zeelandia from both sides of land and sea, and he wrote a letter to the Dutch Taiwan governor Frederick Coyett to ask him to surrender to Zheng army that: "You just need to return back the lands that I owned before, and you may take the treasures and jewels as much as you want" (Lian, 2011). But Coyett was not willing to receive the fact that he already lost the war, and refused Koxinga's induce to capitulate. Because the Dutch had ruled Zeelandia for a very long time, it's really a solid castle, Koxinga sent all the army except the one who surrounded the castle to many areas around the island to open up wasteland, then he can get more army provisions to support a long-time surrounding for the Zeelandia.

But the Dutch were not willing to fail, and they asked for help to Batavia. The East India company's headquarters sent a main fleet to reinforce Taiwan, and help to rescue the Zeelandia. But Koxinga organized elite troops of both sides of sea and lands to defend, and finally frustrated the attempt of the Dutch, and continued the surrounding of Zeelandia. After such a failure, the Dutch were afraid to fight against Koxinga in front, by the time a traitor named Geng Jimao, who worked for the Qing government advised the Dutch to attack the base of Zheng family in the mainland, Xiamen. Then the Dutch planned to take the chance to pie down Zheng army, but the commander of the Dutch was frightened to death by the Zheng army, and led the warships under his order flee back to Batavia. Then Zeelandia fell into a much depressing situation.

In Dec. 16th, the same year, a German sergeant named Hans Jurgen Radis in the Dutch army defected to the Zheng army. He reported the detailed circumstance of Zeelandia to Zheng Chenggong, and advised him to concentrate the main troops on capturing the Utrecht bunker, to get a place to bombarded the Zeelandia and completely collapsed the morale of the city. Zheng Chenggong took the advice, and bombarded on the Utrecht bunker, finally captured the defensible bunker. At this point, the morale of the Dutch who stick to defend the city for half a year was completely collapsed.

In Jan. $27^{\text {th }}, 1662$, the Dutch council of Taioan decided to give up all the resistance and asked for cease-fire. Feb. 1st, Frederick Coyett signed on The armistice agreement. At this time, the war that Zheng Chenggong led to recover Taiwan ended as the result of the complete victory of the Chinese. It was the second great victory after nearly thirty years of Zhengzhilong's great victory between Chinese and the Westerners in the west pacific ocean. Taiwan, the bright pearl of Pacific ocean came back to the Chinese nation from then, and completely realized its Chinese civilization. And the Chinese, firstly got a springboard and base which could live permanently and extend to the outside world. The Chinese were never so near to the dream of the establishment of a great Sea Empire.

\subsection{Frustrated Dream - The Dream of Zheng Chenggong to Conquer Luzon and His Death in a Very Young Age}

The Recover of Taiwan by Zheng Chenggong can be regarded as a signal, which means that he originally focused his eyes on fighting against Qing government and reviving China, but now Zheng Chenggong began to focus his eyes on the vast oceans again. The Confucius said that: "Since my way [doctrine] is making no headway, I shall get upon a raft and float out to sea". Since the mainland has already fallen into the hands of the Manchurian, and the power of Manchurian was still very strong, then how about doing something like his deceased father to establish a great sea empire at first, to accumulate the powers of Chinese people, then turn to recover the mainland, and revive China again.

So, when Zheng Chenggong finished his great cause to recover Taiwan, he turned his eyes to the southern Ocean countries which were very rich, and the first to bear the brunt was nothing more than the Luzon islands which were controlled by the Spanish Colonists. 
The Luzon islands, from the ancient times there were Chinese living and doing business, were the important doors linked the Eastern Asia and the South Ocean countries. But after Spanish people occupied Manila and established the colonies, the Luzon islands descended to be the place where Spanish plundered and squeezed cruelly. And the Chinese people here, because they are smart and rich, were the first choice of the Colonists. After the failure by Linfeng to strike Manila in 1578, in 1603, the Spanish conducted the first massacre on Chinese in large scale, in that massacre, the Spanish took the way like the modern Nazis:"The Chief ordered to list the names of Chinese, and divided each 300 people to a group, and killed them group by group" (Zhang, 1974). The Chinese who had lived in Luzon for more than 400 years, were nearly completely destroyed. After that, only in the $17^{\text {th }}$ century, Spanish planed two more massacres on Chinese people, in the massacre of 1662, the Spanish even used cannons to fire on the Chinese communities, which caused at least 5000 people's death.

Because of the retroaction of Spanish, Zheng family who worked as the protector and Patron saint for all the overseas Chinese were unable to tolerate. After two months of the recovery of Taiwan, Zheng Chenggong warned the Spanish governor of Manila about his crime for killing and plundering Chinese, and asked him to"Forsake heresy and return to the truth, then pay tribute to my country" (Koxinga, 2014). But the governor not only didn't follow the advice, but also conducted massacre on Chinese for the third time. Zheng Chenggong was so angry that he ordered the army to be mobilized, so that they can go across the ocean to attack Manila in anytime.

As for the power that Zheng family had this time and the popularity of just recovered the Taiwan island, it's not a very big matter for Koxinga to conquer Manila, and it was in fact a great chance for the Chinese to jump to the deep ocean and made a final bid for victory with the westerners. But, a sudden change in the situation made the hero for the time Zheng Chenggong lost this chance forever.

Just before Zheng Chenggong decided to dispatch troops, he got intelligence that his eldest son Zheng Jing who was in charge of the defense of Xiamen committed adultery with his wet nurse. Zheng Chenggong was a man of very bad temper, when he heard the message he was suddenly very angry, and ordered to kill Zheng Jing and the wet nurse. This apparently made a mountain out of a molehill, and the officers in Xiamen refused to execute the commander. Besides Zheng Chenggong forced followers to move their family from Xiamen to Taiwan, which drew widespread discontent, so the Jinmen and Xiamen cut their connection with Taiwan from then. One disaster after another was that Zheng Zhilong and the whole Zheng family members who surrendered to Qing government were exterminated by the Manchurian, and even the ancestral graves of Zheng family were destroyed by the Qing government. Zheng Chenggong was so angry about all these, and he suffered from dysentery, finally passed away because of this, and at this time, he was only 39. Before his death, he shouted:"I feel too shame to meet the late emperor underground!” (Lian, 2011). And he scratched his face and died. Such a great hero died at such a young age, really made us later generation feel very regretful about that.

After that, the originally imperative Luzon attacking plan was adjourned indefinitely, the already opened door of Sea Empire of China was gradually lost by Chinese ourselves.

4.6 The Tune Lingered in the Room - The Management of Taiwan and the Protection of Sea-Power by the Kingdom of Tungning

Although Zheng Jing was far less from his father and grand father in the talent and ambitions, but he was very clear-headed when he dealt with the important matters. He led army to surround Jilong, finally defeated the efforts of the Dutch to recover their colony in Taiwan.

At the same time, Zheng Jing succeeded the mantle of his father and grandfather, continued to run a powerful Sea Trade Empire, and he developed the trade relationship with Japan, and became the main trade partner of Tokugawa Japan. By the way, he started to establish the trade relationship with the British East India Company, and signed Treaty of Commerce (The document committee of Taiwan province, 1990) to get advanced weapons and technology to balance the expansion of the Power of Dutch.

As for the Long-cherished wish of his father - The Conquer of Luzon, Zheng Jing has put it on his agenda for times. In 1672, Zheng Jing has held a conference to talk about the possibility to attack Luzon, but because of the opposition by Feng Xifan and the outbreak of Revolt of the Three Feudatories, it was finally canceled. But, until the end of Zheng family group, Zheng family always played a very important role in the oceans, and always protected the safety and freedom of navigation of the Chinese trade ships which sailed across the oceans.

It was a pity that Zheng Jing had been influenced by his father Zheng Chenggong's early ideas, the Zheng group after Zheng Jing's main goal always focused on the recovery of mainland and the expansion to the overseas and the management of sea trades could always only be the relatively minor goals. As a result, whatever the repeatedly grounding plan to conquer Luzon or the tepid attitudes toward the overseas' trade management, had all reflected 
that characteristic. In a word, this time's Zheng family group was never the group in the past time which took active part in the maritime expansion and tried hard to maintain the sea rights, but an occupying power which focused on the mainland and regarded the sea trade as assistance for the Land strategy only.

But, at this time, Qing government already established a foothold in China, it was not easily shaken by a sea power like Zheng family group. Although Zheng army took the chance of the Revolt of the Three Feudatories to conduct a general counteroffensive to Fujian, but as the Revolt of the Three Feudatories were finally suppressed by the Qing government, Zheng group couldn't defend the counterattack by the Qing army, finally lost all the land that they had recovered, and retreated to Taiwan. That failure had beaten Zheng Jing heavily, finally he died because of anger and illness, when he was only 40 years old.

After Zheng Jing's death, Zheng group fell into civil strife again. After a serious internal strife, the successor of Zheng family Zheng Keshuang was too young (only 12 then) to administer the affairs of the state, so the state affairs were mainly decided by Feng Xifan and Liu Guoxuan, and those two people had no ambition to make progress, but only wanted to maintain the status quo. But Qing government adopted the advice from the former general of Zheng family Shi Lang, determining to destroy the Zheng family government. And the Zheng government had no power to compete with the elite navy led by Shi Lang after so many civil strife. In the battle of Penghu, Zheng army was beaten heavily, Zheng Keshuang had no choice but to listen to Feng Xifan's advice, tonsured and surrendered to the Qing government.

Until now, the Zheng family group which was established by Zheng Zhilong, expanded by Zheng Chenggong, conformed by Zheng Jing and passed four generations completely collapsed. And the Qing government, shrank quickly, even almost abandoned Taiwan, their only goal was to focus on the internal affairs in the mainland, and used many kinds of limitations to suppress the Han nation which was the majority of population, then established a stable country ruled by the Manchurian. At this point, the last hope for the ancient Chinese people to conquer the oceans was completely collapsed.

\subsection{Brief Summary}

After Zheng Zhilong won the historical victory in Liaoluo port, Jinmen, the Chinese nation faced a chance which is difficult to meet in a thousand years, if Chinese can develop in such a trend for one hundred or at least dozens of years, Chinese nation will surely have a bright future which is full of marine elements. But, unfortunately, the Zheng Zhilong's flourishing age of sea happened to meet the unprecedented war and the northern barbarian Manchurian's conquest. Finally, Zhengzhilong decided to yield to the new super power in land - The Qing government, and gave up the freedom to pursue for the vast oceans. In that moment the marine causes of the Chinese nation seemed nearly to be fall into the boundless darkness again.

Luckily, Koxinga stepped forward bravely this time, as a young scholar, and undertook the rise and fall of the country. But, just as Tan Tan pointed out in his thesis (Tan, 2010), in Koxinga's time, the Chinese sea powers can never have the smooth development circumstance as Zheng Zhilong's time, but Tan Tan's discussion mainly concentrated on the internally dilemma that Koxinga faced in the new time background, in other words, the fall of Ming and the rise of Qing and its influence on the Zheng family group. But in fact the situation that Koxinga faced was beset with troubles both internally and externally. And this macroscopic background also decided the characteristics of the relationships between different sides in the time of Zheng Chenggong and the time after him.

First of all, as for the relationship between Zheng group and the government, the relationship reached an unprecedented incompatible condition. Because of the special background of times that the country was defeated and the home was lost, the both sides of Zheng Chenggong and the Qing government couldn't bear the existence of each other. Also because of that, the support from land and from the authority was the weakest compared to the former sea-merchant groups in Zheng Chenggong's time. Zheng Chenggong was a lone hero who fought the powerful enemies alone.

Secondly, as for the relationship between Zheng group and the western countries, their struggles turned white-hot, and occupied the most of the time. That's mainly because of the gradually rising up of the comprehensive strength of the western colonial countries. As the strength of Netherlands became stronger in southeastern Asia and Japan, the western countries represented by the Netherlands and Spain's covet to the Chinese coastal area rose up day by day, added that there are great changes and unrest after the falling of Ming dynasty in Chinese mainland, which strengthen the Dutch's covet to China. To protect the benefits of own group, consolidated the territorial seas of China, and expanded the sea-powers there were great contradictions between Zheng Chenggong and the western countries, finally escalating into a large scale war like the recovering war of Taiwan. 
At last, in the strategy of sea-powers, Zheng group already had a very clear sense of sea-power, and as early as in 1646, Zheng Chenggong had put forward his ideas in his famous "Yanping suggestions" that: "We need to control the natural barriers and chose suitable generals to make progress, then use the warships cooperated to attack, finally made our country rich through the overseas trade" (Jiang, 1960). And it's surely an apparently sea strategy, and it absorbed his father and many other sea-predecessor's experiences, is really an important strategic measure. In this idea, it looked the overseas trade as an important economic basic, which broke the traditional Chinese economic philosophy of Proagricultural and anticommerce, and was a typical thinking model of maritime powers, and had many similarities as the Mercantilism in the same time's Europe.

At the same time, Zheng Chenggong spared no efforts in protecting the benefits of Chinese sea-merchants and the expansion of their scope of business, and had many contradictions with the Dutch side in the allocation of interests. Finally, he took the strategy to use both the way of military deterrence and economic sanction. At the same time, to get a stable trade and military base, he concentrated the forces and conquered Taiwan from the hands of the Dutch successfully, that's also an important achievement that Chinese made in the maintenance of sea-power. Although Zheng Chenggong died in a very young age, and many of his envisages were not realized and developed yet, but all the four generations of Zheng family all made the best they can to protect the sphere of influence and the legitimate rights and interests of Chinese in the southeastern China and the vast ocean of Taiwan and the southern oceans, and their power was always one of the strongest military powers in the west pacific ocean.

\section{The Overview and the Inspirations to Today'S Strategies on the Sea-Powers}

\subsection{The Overview}

After the complete failure of the navigation of Zheng He, the management and development in the sea in Ming dynasty were mainly formed by the nongovernmental powers, and the development of the sea-merchant groups were always accompanied the Ming dynasty from the beginning to the end, and we can divide it into three stages just as I said before. And in my opinion, the overview and conclusion of the relationships between sea-groups, Ming government and western power and the developing process of the sea-merchant groups in the whole Ming dynasty are where the historian who study on these subjects didn't pay enough attention to before. Next, I will draw a brief conclusion to the development of the sea-merchant groups in Ming dynasty.

At first, as for the relationship between sea-merchant groups and the governmental power, in general they came from confrontation gradually to confluence. From the confrontation against each other to the on-offs in the middle, finally to the complete union of the two sides, there was a long process. But after the falling of Ming dynasty and the entry of Manchurian, although the sea-merchant groups which were represented by Zheng family became the representative of Ming government on one side, but it became incompatible with the new central Qing government, which was surely the backwards of history, and also caused that the development of Chinese sea power was contained heavily, which was surely a great regret.

Secondly, as for the relationship between nongovernmental power and western countries, they came from cooperation gradually to confrontation in general. From the first stage's cooperation to fighting against the government, to the middle stage's on and offs, finally to the complete confrontation against each other, which seems just the opposite side of the relationship between sea-merchant groups and the governmental power. But, at the same time the relationship between nongovernmental power and western countries also went through a tortuous course. In a word, the relationship between the three sides of sea-merchants, official power and the westerners was caused by the growth and decline of the powers of the three sides.

Finally, as for the strategy of sea-power, in general it was in a tendency of from rough to meticulous, from local to overall situation, and from lack to fully prepared. At the early age, the sea-merchants group's principal contradiction was concentrated on the contradiction with the authority's sea-trade limit policy, there was no apparent threat from the western countries. As a result at this time there wasn't a very apparent goal of sea-power strategy. In the middle stage, because of the continued rising of western countries, and the sea-trade limit was loosen by Ming government, the main contradiction was transferred and a relatively clear sea-power strategy became a necessity. By the way, to maintain the benefits of Chinese merchants and protect the safety of sea, the expansion of sphere of influence became the inevitable choice. At the later stage, because of the continuing rising of non-governmental powers, and the government power became weaker, the two sides between the contradiction changed into the western powers and the sea-merchants groups. And the nongovernmental groups began to consider themselves to be the representative of government, and started to put forward well defined goals of sea-power, and established tight maritime management organizations and strong navy to combat western countries. Then safeguarded sovereignty of China and the expanded sphere of influence and management areas of Chinese all became an important component of the sea-power strategies. 
At the same time, the way to struggle for sea-power gradually became diversified, the economic sanctions and the military deterrence became the two main ways of them.

In general, the falling and rising among the three sides and the sea-power strategies they choose, were mainly based on the reason of the power shift of three sides. As the passing of time, the controlling force of the central government became weaker, and the nongovernmental power and the western power were developed sharply, and the contradiction and battle between the two sides gradually became the most important affair and challenge for the late sea-merchants groups like the Zheng family group. And the Chinese sea-groups didn't lag behind in the struggles with the western powers. On the contrary, they became braver after several battles, and were inspired to have stronger vitality and comprehensive strength, and gradually became the strongest enemy and opponent of westerners in the West Pacific oceans, which was very enough for the later generations to memorize and be very proud of them.

It's a pity that everything however brilliant they had been, everything will pass. The Great sea Empire of Zheng family finally disappeared from the earth by the union force of Qing empire in the land and the western countries in the sea, but the Maritime pioneers who came first on the list could leave a lot of inspirations to China which is in the Renaissance and the whole world.

\subsection{The Inspirations to Today'S Strategies on the Sea-Powers}

Although the sea-pioneers' deeds and strong powers in Ming dynasty finally had gone with the wind, but their past things can leave behind many beneficial enlightenment to the later generations.

First of all, as for a country, especially a developing super power, to establish a strong sea deterrent, to prevent the sea-power was not been infringed by other countries was of great importance. Just as the scholars as Ni Lexiong pointed out $(\mathrm{Ni}, 2012)$, that a society which rely on the overseas trade should necessarily use the naval power to survive. Until the late $19^{\text {th }}$ century, American marine expert Alfred Thayer Mahan put forward the importance of protecting the sea-power and the ways to protect it in his masterpiece Sea Power Theory. But hundreds of years ago, in the $17^{\text {th }}$ century, the leader of sea-merchant groups Zheng Zhilong and his son Zheng Chenggong had very clear idea of sea-powers, and also knew the importance to maintain the sea-powers. Although their practice in protecting the sea-powers was suspended because of the destruction of Zheng family group, their actively protecting the sea power and the management in southeastern Asia, were all very worth for us today to refer to. After the prelude of modern times, especially today which had gone through several times of industrial revolutions, to maintain the Strategic security without a strong sea force was nearly impossible. To continue the development of economy, and push China to a further revival, the strong power to maintain the sea-power is a necessity.

Secondly, as the ways to protect and expand the sea-powers, we can divide them into two sides: The strategy side and the tactics side. As for the strategy side, the inspirations that we can take from the sea-merchants of Ming dynasty are that: We must defend the invasion in the sea if we want to defend our territory, and to make sure the safety of the mainland we must consolidate the defense of Taiwan, and to consolidate the defense of Taiwan we must try hard to maintain the security of shipping lanes in Southeastern and Eastern Asia. Taiwan, is the gateway to enter the China seas, and it became even more important after The Age of Great Discovery. As for today's China, Taiwan has a similar significance as the time of Zheng family: If Taiwan came back to the control of China, the Chinese sea-power strategies may be in an unprecedented favorable position. If we take a step back, we can make sure the security of the offshore waters, if we take a further step, it could act as an important base to trade and have military cooperation with the whole East and Southeast Asian countries. At the same time, once we recover Taiwan, the power of America may be badly hit, and China will surely play a decisive role in the Asian affairs. As a result, to recover and consolidate Taiwan is the imperative choice for China in the future.

At the same time, just as many sea-merchants groups had seen, the southeastern Asia, because of its geographical position and abundance in resources, it was meant to be the area that the reviving Chinese power would take active part in it. Besides there were a large number of Chinese who lived in the southeastern Asia from ancient times, and these Chinese have played very important roles in the economical and political areas of the countries they lived in. It can be said that China is rightly to have really great voice about the southeastern Asian affairs. Besides now some Southeastern Asian countries were instigated by outer powers, and had serious disputes with China on some islands in South China sea. Not to mention that the maritime lifeline of China must go through the Strait of Malacca in Southeastern Asia. As a result, China has to establish strong sea force, to maintain the benefits of Chinese in the sea and have greater voice in the regional and global affairs.

At the same time, the cooperation relationship between the sea-merchants groups and Japan can also give some beneficial references to today's relationship between China and Japan which come to a deadlock. China and Japan, which are two countries that are close neighbours separated only by a strip of water, and had a very long history of 
friendship, and the nongovernmental cooperation and contacts had a even longer history. Although in the modern time, after two large scale wars between the two countries, the traditional friendship between the two countries was destroyed completely, but the nongovernmental cooperation and communications were still very close. According to the development history of the merchants groups, Japan always acted as the backyard and supporter of the sea-merchants groups of China. And precisely because of the support from Japan that the sea-merchants groups had a relatively stable base area, and were not so easy to be destroyed by the united army of Ming government and the westerners. But today, because of the historical reasons after World War II, Japan sides with the united states for a long time, and which also let the developing China trapped in the islands chains which are settled by America and only has very limited strategic space. But if Japan could change her foreign policy, return back to the union of Eastern Asian culture, and form joining forces to balance the western forces, which will surely change the situation of Western Pacific Ocean completely. Of course, it's always easier to destroy than to rebuild, the relationship between China and Japan which has been destroyed completely by historical factors is extremely difficult to recover again, besides there is America who is placing obstacles in the way, it's sure that we can't realize our goal in a short period of time. But, if China could follow the example of the past strategy of Cultural influential power, express the rising comprehensive national strength as the Cultural charisma, and strengthen the identification of China and Chinese cultural among the common people of Japan. At the same time, China should continue to develop the maritime force and comprehensive national strength of China, finally force America power evacuate from Asia, and I'm quite sure then the relationship between China and Japan will meet a new spring time.

As for the part of tactics, the tactical ways to protect sea-power by the sea-merchants groups in Ming dynasty were also very strategical and worth for us to draw lessons from them. To protect the sea-power, and faced such a situation which was beset with troubles internally and externally, the sea-merchants groups took very flexible and clear ways to deal with the enemies. In Ne Lexiong's thesis, he stressed "the importance of establishing a modern navy that could be used to defend the overseas interests and the maritime lifeline of China" (Ni, 2012), but he ignored the importance of economical ways in the struggle to maintain the sea-power.

First and very important point is that in the struggle to maintain the sea-power, sometimes taking the strategy of economic war is much effective than pure military struggle. Faced with the overbearing Dutch East India Company, Zhengzhilong and Zheng Chenggong all took the way of economic wars. At this time, ways like sanction, embargo and the economic blockade had already become the commonly used methods of Zheng family in competitions. And through several times of economic wars, Zheng family group got very impressive results. That's the matter that today's China's policymakers should take into consideration, facing the unprecedented complex situation in South and East China sea, China should not only had the military strength enough to threaten the other side, at the same time, should know how to use economical ways to balance the opponent, only in that way can China get better results and spend a smaller price.

Secondly, there must be the military force that enough to deter and overwhelm the opponent. Faced with the competition which become much fiercer day by day, only through the economical ways people often can't reach their goals to deter and overwhelm the opponent. To reach the strategic objectives, there must be a military force that is strong enough to form an effective deterrent. In the struggles between western powers, Zheng Chenggong and his father often worked along both sides, taking both the economical ways and the military ways. At the same time, to get a complete strategic victory, it's the necessity to take the military means.

Although the pioneers of sea in the Ming dynasty's glories and dreams all had gone with the wind, the enlightenment and lessons they left for the later generations still have the values to be chewed and deliberated by us contemporary.

\section{Reference}

Cai, J. K. (1967). County annals of Chenghai. Taipei: The Chengwen Press.

Chen, S. G. (2000). The Dutch in Formosa. Taipei: Liao Jing Publishing Company.

Huang, D. M., \& Wu, J. Q. (Eds.). (1996). The ancient and modern collection of poems of Quanzhou. Quanzhou: The Citongyin Press of Quanzhou.

Ji, L. Q. (1984). The Northern Strategies of Late Ming Dynasty. Beijing: Zhonghua Book Company.

Jiang, R. S. (1960). Taiwan Record. Beijing: Zhonghua Book Company.

Koxinga. (2014). In Wikipedia, the free encyclopedia. Retrieved November 30, 2014, from http://en.wikipedia.org/ wiki/Koxinga

Li, G. Q., \& Liu, J. K. (2014). Challenges and Modified Tone. Social Science Front, 1, 95-101. 
Lian, H. (2011). The general history of Taiwan. Beijing: SDX Joint Publishing Company.

Ni, L. X. (1997). The Study On the Zheng Chenggong's Navy From the Perspective of Social Transformation and the Sea Supremacy. Military Historical Research, 4, 129-132.

Ni, L. X. (2012). The Significance of Sea Power Practice in the Time of Zheng Chenggong to Contemporary China. Journal of East China Normal University, 2, 16-22.

Tan, T. (2010). On The Survival Plight of The Sea-Merchant Group of Zheng Family in $17^{\text {th }}$ Century. Academic Journal of Zhongzhou, 176, 193-197.

The document committee of Taiwan province. (1990). The history of Taiwan (pp. 204-205). Taipei: Jongwen Books Company.

Wang, E. Z. (2005). On the Status of Sea-Merchant Group of Zheng family In $17^{\text {th }}$ Century. Academic Monthly, 8 , 103-107.

Xia, B. B. (2002). Zheng Zhilong: The Great Merchant In the $17^{\text {th }}$ century's Fujian Sea-area. Academic Monthly, 4, 58-63.

Xue, E. (2011). The pirates of great powers: The Chinese pioneers in the oceans. Shanxi: Shanxi people press.

Zhang, H. J. (2009). The seven faces of Ming dynasty (pp. 315-318). Nanning: Guangxi Normal University press.

Zhang, T. Y. (1974). History of Ming. Beijing: Zhonghua Book Company.

Zhang, X. (1985). Dongxiyang Kao. Beijing: The Commercial Press.

\section{Copyrights}

Copyright for this article is retained by the author(s), with first publication rights granted to the journal.

This is an open-access article distributed under the terms and conditions of the Creative Commons Attribution license (http://creativecommons.org/licenses/by/3.0/). 